\title{
Phytotoxic Arylethylamides from Limnic Bacteria Using a Screening with Microalgae ${ }^{\dagger}$
}

\author{
RAJENDRA P. MASKeY ${ }^{\mathrm{a}}$, RATNAKAR N. ASOLKAR ${ }^{\mathrm{a}}$, EdWIN KAPAUN ${ }^{\mathrm{b}}$, \\ IRENE WAGNER-DÖBLER ${ }^{\mathrm{c}}$ and HARTMUT LAATSCH ${ }^{\mathrm{a}, *}$ \\ ${ }^{\text {a }}$ Department of Organic Chemistry, University of Göttingen, \\ Tammanstrasse 2, D-37077 Göttingen, Germany \\ ${ }^{\mathrm{b}}$ Institute of Plant Pathology, University of Göttingen, \\ Griesebachstrasse 8, D-37077 Göttingen, Germany \\ ${ }^{c}$ Department of Microbiology at the National Research Institute for Biotechnology, \\ Mascheroder Weg 1, D-38124 Braunschweig, Germany
}

(Received for publication December 25, 2001)

\begin{abstract}
$N$-Phenylethylamides 1a $\sim 1$ f, were isolated from cultures of three limnic strains GW90a, GW102a and GW73a. Strain GW102a delivered additionally the compound cyclo(isoleucyldehydroalanyl) (2). The structure of these compounds were assigned by a detailed spectral analysis. Due to their potential use as herbicides, various related compounds 1a, 3, 4a and 4b were synthesized. The minimum inhibitory concentration (MIC) against Chlorella vulgaris, Chlorella sorokiniana, Chlorella salina and Scenedesmus subspicatus ranged from 100 to $12.5 \mu \mathrm{g} / \mathrm{ml}$. All these amides were found to be inactive against Mucor miehei, Candida albicans, and some bacteria.
\end{abstract}

Aquatic microorganisms are a rich source of new and biomedically relevant constituents ${ }^{1)}$. We have focussed our efforts to explore the potential of biologically active marine and limnic bacterial extracts for antimicroalgal, antibacterial and antifungal activity ${ }^{2)}$. In the course of this screening, extracts of the limnic strains GW90a, GW102a and GW73a were shown to possess potent antimicroalgal activity.

Fermentation of strain GW90a and separation of the extract afforded four new $N$-phenylethylamides $1 \mathbf{b} \sim \mathbf{1 e}$. From the strain GW102a in addition to the metabolites above, the new compounds 2-methyl- $N-(2$ '-phenylethyl)butyramide (1f) and cyclo(isoleucyldehydroalanyl) (2) were isolated, while another limnic strain GW73a delivered the arylethylamide 1d. Due to their expected biological properties, arylethylamides $\mathbf{1 a}$ and $\mathbf{3}$ as well as their analogues $4 \mathbf{a}$ and $\mathbf{4 b}$ were synthesized. This paper deals with the taxonomic characterisation of the producing organisms, the production, isolation and synthesis of arylethylamides and analogues, and describes their antimicroalgal activity.
Taxonomic Studies of Producing Strain

The strains GW73a, GW90a, and GW102b were enriched from a sediment sample from the waste storage site Georgswerder close to Hamburg, Germany, and were able to grow on a minimal medium containing biphenyl as the sole carbon source.

The strains were investigated by FAME (fatty acid methyl ester) analysis and shown to belong to a tight cluster with an Euclidean distance $<10$. On the basis of the FAME profiles, the strains were assigned to the Nocardiopsis group of organisms but could not be identified further. Sequencing of the 16S rDNA showed GW73a to be most similar but not identical to Bacillus cereus ( $98 \%$ sequence identity), GW90a to an unknown Bacillus strain (96\% sequence identity) and GW102b to Bacillus thuringiensis (96\% sequence identity). Thus, these strains probably represent new species or subspecies within the genus Bacillus.

\footnotetext{
+ Art. No. XIII on Marine Bacteria. Art. XII: V. J. R. V. MukKu, M. Speitling, H. LAATSCH and E. Helmke: New butenolides from two marine Streptomycetes. J. Nat. Prod. 63: 1570 1572, 2000.

* Corresponding author: hlaatsc@gwdg.de
} 
Fig. 1.

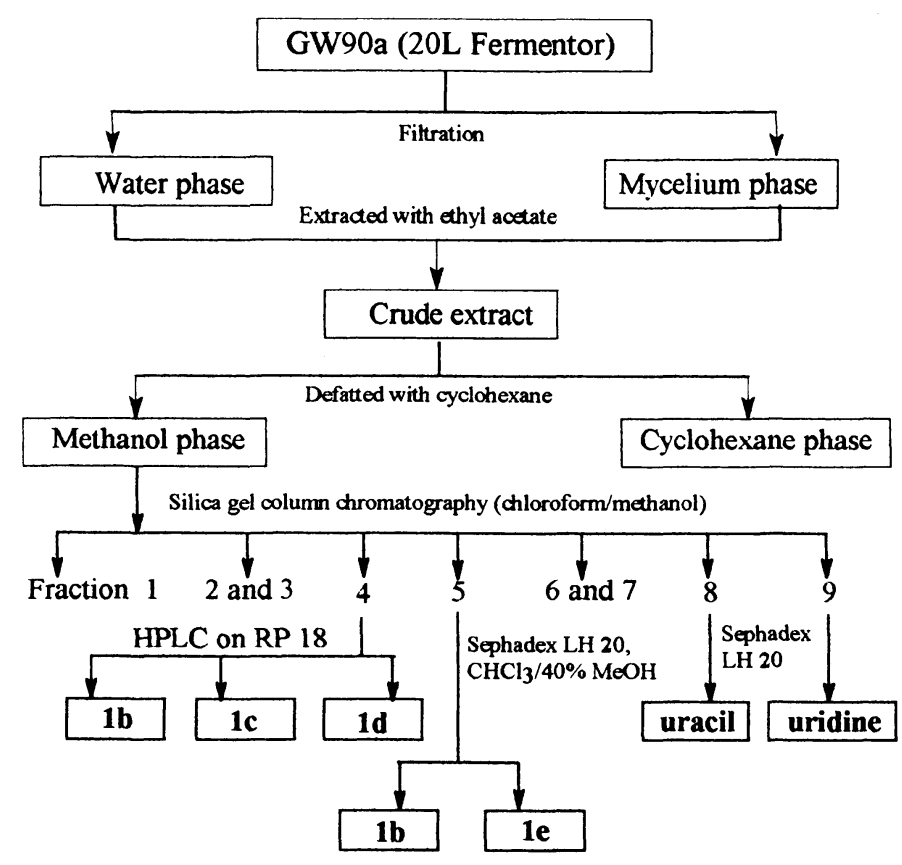

Work-up of the strain GW90a

Fermentation and Isolation

The producing limnic strains GW90a, GW102a, GW73a were inoculated from agar culture into Erlenmeyer flasks with Luria-Bertani medium and incubated for 3 days at $28^{\circ} \mathrm{C}$. Upscaling was done in 20 -liter jar fermentors under similar conditions.

The ethyl acetate extract, obtained after work-up of the culture, was defatted with cyclohexane and subjected to silica gel column chromatography to separate various fractions.

Activity screening of the fractions was done by agar diffusion tests using the algae Chlorella vulgaris, Chlorella sorokiniana, Chlorella salina, and Scenedesmus subspicatus. The active fractions were purified by HPLC and Sephadex LH 20 to afford six new colourless compounds namely $N$-(2'-phenylethyl)propionamide (1b), $N$-(2'-phenylethyl)isobutyramide (1c), 3-methyl- $N-\left(2^{\prime}-\right.$ phenylethyl)butyramide (1d), $\quad N$-(2'-phenylethyl)hexanamide (1e), and 2-methyl- $N$-(2'-phenylethyl)butyramide (1f) along with the known compounds cyclo(isoleucyldehydroalanyl) (2), $\quad N$-(2'-phenylethyl)acetamide (1a), $N_{\beta}$-acetyltryptamine, cyclo(tyrosylprolyl), cyclo(leucylprolyl), uridine, uracil, and anthranilic acid. All these compounds were identified by IR, ${ }^{1} \mathrm{H}$ NMR, ${ }^{13} \mathrm{C}$ NMR and EI-MS/CI-MS and by comparison with data from AntiBase ${ }^{3)}$.

\section{Results and Discussion}

The molecular formula of $\mathbf{1 b}$ was determined to be $\mathrm{C}_{11} \mathrm{H}_{15} \mathrm{NO}$ by HR-MS of the molecular ion at $\mathrm{m} / \mathrm{z}$ 177.1. The IR spectrum showed bands at 3275 and $1648 \mathrm{~cm}^{-1}$, pointing to the presence of an amide group. The ${ }^{1} \mathrm{H}$ and ${ }^{13} \mathrm{C}$ NMR data confirmed the presence of an amide carbonyl and indicated three methylenes, one methyl and a phenyl group. Based on the spectroscopic information and the comparison of NMR data with the known amide 1a, the structure was assigned as $N$-(2'-phenylethyl)propionamide (1b) and finally confirmed by synthesis.

The DCI mass spectra of three further isolated compounds led to the molecular weights of 191, 205 and 219 Dalton, respectively. The ${ }^{1} \mathrm{H}$ NMR spectra showed an phenylethyl system as in $\mathbf{1 b}$ with the variation in the signals for the acid, which suggested these metabolites to be phenylethylamides of homologous acids. The spectroscopic data of these compounds led to $N$-( $2^{\prime}$-phenylethyl)- 
Table 1. Physico-chemical properties of arylethylamides $\mathbf{1 a} \sim \mathbf{b}, \mathbf{3}$, and $\mathbf{4 a} \sim \mathbf{b}$.

\begin{tabular}{|c|c|c|c|c|c|c|c|c|c|}
\hline & $1 \mathbf{a}$ & $1 b$ & $1 c$ & Id & 1e & 1f & 3 & $\mathbf{4 a}$ & $4 b$ \\
\hline m.p. $\left({ }^{\circ} \mathrm{C}\right)$ & 85 & 52 & $80-81$ & 64 & $57-58$ & $57-58$ & 118 & 70 & 120 \\
\hline$R_{\mathrm{f}}^{\mathrm{a})}$ & 0.48 & 0.56 & 0.63 & 0.65 & 0.65 & 0.65 & 0.78 & 0.61 & 0.78 \\
\hline M.F. & $\mathrm{C}_{10} \mathrm{H}_{13} \mathrm{NO}$ & $\mathrm{C}_{11} \mathrm{H}_{15} \mathrm{NO}$ & $\mathrm{C}_{12} \mathrm{H}_{17} \mathrm{NO}$ & $\mathrm{C}_{13} \mathrm{H}_{19} \mathrm{NO}$ & $\mathrm{C}_{14} \mathrm{H}_{21} \mathrm{NO}$ & $\mathrm{C}_{13} \mathrm{H}_{19} \mathrm{NO}$ & $\mathrm{C}_{15} \mathrm{H}_{15} \mathrm{NO}$ & $\mathrm{C}_{10} \mathrm{H}_{13} \mathrm{NO}$ & $\mathrm{C}_{15} \mathrm{H}_{15} \mathrm{NO}$ \\
\hline \multicolumn{10}{|c|}{ P } \\
\hline Calcd. & 163.09971 & 177.11536 & 191.13101 & 205.14666 & 219.16231 & 205.14666 & 225.11536 & 163.09971 & 225.11536 \\
\hline Found & 163.0997 & 177.1154 & 191.1310 & 205.1467 & 219.1623 & 205.1467 & 225.1154 & 163.0997 & 225.1154 \\
\hline
\end{tabular}

a) eluent: $\mathrm{CHCl}_{3} / 10 \% \mathrm{MeOH}$

isobutyramide (1c), 3-methyl- $N$-(2'-phenylethyl)butyramide (1d) and $\mathrm{N}$-(2'-phenylethyl)hexanamide (1e).

The CI and EI mass spectra revealed for another compound a molecular weight (205 Dalton) identical with that of 1d. The ${ }^{1} \mathrm{H}$ NMR spectrum showed it to be also a phenylethylamide, the acid part contributing a sextet at $\delta$ $2.01(1 \mathrm{H})$, two multiplets at $\delta 1.63$ and $1.39(1 \mathrm{H}$ each), a doublet at $\delta 1.07(J=8 \mathrm{~Hz}, 3 \mathrm{H})$ and a triplet at $\delta 0.86$ $(J=8 \mathrm{~Hz}, 3 \mathrm{H})$. The final structure was assigned by aid of the $\mathrm{H}, \mathrm{H}$ COSY spectrum as 2-methyl- $N-\left(2^{\prime}\right.$-phenylethyl)butyramide (1f) and also confirmed by synthesis.

The ${ }^{1} \mathrm{H}$ NMR spectrum of the compound 3 showed two broad $\mathrm{D}_{2} \mathrm{O}$ exchangeable signals at $\delta 10.44(1 \mathrm{H})$ and 8.38 $(1 \mathrm{H})$ for $\mathrm{NH}$ and/or $\mathrm{OH}$ groups. The signals at $\delta 5.12(1 \mathrm{H})$ and $4.78(1 \mathrm{H})$ were attributed to olefinic protons. A triplet of doublet at $\delta 3.96$ for a methine proton connected either with a nitrogen or an oxygen atom, a $1 \mathrm{H}$ multiplet at $\delta$ 1.80 , a doublet of triplet $(2 \mathrm{H})$ at $\delta 1.56$ and a doublet for six protons at $\delta 0.86$ (isopropyl group) were observed at the aliphatic region. The ${ }^{13} \mathrm{C}$ NMR and APT spectrum of this compound showed eight signals. The signals at $\delta 166.4$ and 158.2 were interpreted as carbonyl signal of carboxylic acids, amides or esters. The signals at $\delta 134.6$ and 98.9 represent a $\mathrm{C}=\mathrm{CH}_{2}$ fragment in conjugation with a carbonyl group, while the signals at $\delta 22.1$ were accounted for the two methyl group of an isopropyl residue. The DCI mass spectrum suggested the molecular weight to be 182 Dalton, which further indicated the molecular formula $\mathrm{C}_{9} \mathrm{H}_{14} \mathrm{~N}_{2} \mathrm{O}_{2}$. Finally the structure of the compound was assigned by ${ }^{1} \mathrm{H},{ }^{1} \mathrm{H}-\mathrm{COSY}$, HMQC and HMBC couplings as cyclo(isoleucyldehydroalanyl) (2).

A piperazinedione with the structure of $\mathbf{2}$ has been
Formula 1.

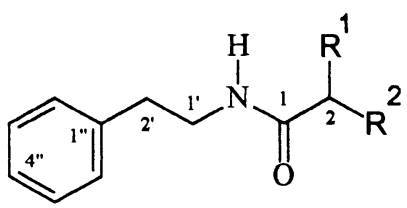

\begin{tabular}{c|cccccc}
1 & a & b & c & d & e & f \\
\hline $\mathrm{R}^{1}$ & $\mathrm{H}$ & $\mathrm{H}$ & $\mathrm{Me}$ & $\mathrm{H}$ & $\mathrm{H}$ & $\mathrm{Me}$ \\
$\mathrm{R}^{2}$ & $\mathrm{H}$ & $\mathrm{Me}$ & $\mathrm{Me}$ & $i-\mathrm{Pr}$ & $n-\mathrm{Bu}$ & $\mathrm{Et}$
\end{tabular}

described recently ${ }^{4}$. The NMR data of both compounds, however, differ substantially in the splitting pattern and chemical shift of the methyl groups, although no diastereomers are possible.

In order to study the structure-activity relationship, the $N$-(2'-phenylethyl)amide 3 and $N$-(1'-phenylethyl)amides 4a and $\mathbf{4 b}$ were prepared from the corresponding $N$ phenylethyl amines and acid chlorides according to the literature and characterized by IR, mass, ${ }^{1} \mathrm{H}$, and ${ }^{13} \mathrm{C}$ NMR spectra.

\section{Antimicroalgal Activity}

Antimicroalgal activities were determined using the agar diffusion method and media as described previously ${ }^{2}$. Table 1 shows the antimicroalgal activities of compounds 


\section{1b $\sim 1 f, 3,4 a$ and $4 b$.}

The results of the agar diffusion tests indicated that the phytotoxicity of the phenylethylamides depends strongly on the lipophilicity of the acid residue of the molecule. That might be the reason for the amides of smaller acids being inactive. The $\left(2^{\prime}\right.$-phenylethyl)hexadecanamide, however, was found to be inactive in the agar diffusion test against all three tested micro alga, perhaps due to poor solubility.

For MIC values, liquid medium was inoculated with test

Fig. 2. H,H-COSY $(\leftrightarrow)$ and HMBC $(\rightarrow)$ couplings of cyclo(isoleucyldehydroalanyl) (2).

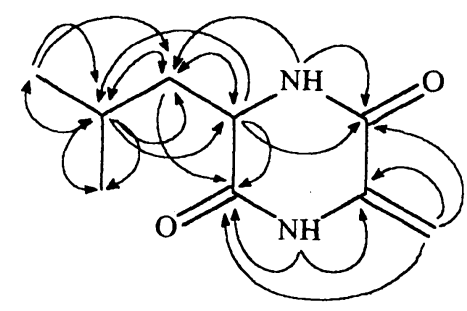

Table 2. Antimicroalgal activity of compounds $\mathbf{1 b} \sim \mathbf{1 f}$, and 3, 4a and 4b in an agar plate diffusion assays at concentrations of $200 \mu \mathrm{g} /$ disc.

\begin{tabular}{cccc}
\hline \multicolumn{4}{c}{ Diameter of Inhibition Zones (mm) } \\
\hline & $\mathrm{CV}^{\mathrm{b}}$ & $\mathrm{CS}^{\mathrm{c}}$ & $\mathrm{SS}^{\mathrm{d}}$ \\
\hline $\mathrm{CE}^{\mathrm{a}}$ & 30 & 30 & 40 \\
$\mathbf{1 a}$ & 0 & 0 & 0 \\
$\mathbf{1 b}$ & 0 & 0 & 0 \\
1c & 0 & 0 & 0 \\
1d & 0 & 0 & 0 \\
1e & 16 & 13 & 20 \\
1f & 0 & 0 & 0 \\
3 & 12 & 13 & 18 \\
4a & 0 & 0 & 0 \\
4b & 20 & 19 & 18 \\
\hline${ }^{\mathrm{a}}$ Crude extract of GW90a, ${ }^{\mathrm{b}}$ Chlorella vulgaris, \\
${ }^{\mathrm{c}}$ Chlorella sorokiniana, ${ }^{\mathrm{d}}$ Scenedesmus subspicatus
\end{tabular}

Formula $2 \sim 4$.<smiles>C=C1NC(=O)C(CC(C)C)NC1=O</smiles>

2<smiles>O=C(NCCc1ccccc1)c1ccccc1</smiles>

3<smiles>[R]C(=O)NC(C)c1ccccc1</smiles>

4a: $R=M e ; 4 b: R=P h e$<smiles>C=C1NC(=O)C(CC(C)C)NC1=O</smiles>

2<smiles>O=C(NCCc1ccccc1)c1ccccc1</smiles>

3<smiles>[R]C(=O)NC(C)c1ccccc1</smiles>

4a: $\mathrm{R}=\mathrm{Me} ; \mathbf{4 b}: \mathrm{R}=\mathrm{Phe}$ 
Table 3. Antimicroalgal activity of phenylethylamides $1 \mathrm{e}, \mathbf{3}$ and $\mathbf{4 b}$ by serial dilution method; MIC $(\mu \mathrm{g} / \mathrm{ml})$.

\begin{tabular}{lrrrr}
\hline & $\mathrm{AD}^{\mathrm{a}}$ & $1 \mathrm{e}$ & $\mathbf{3}$ & $\mathbf{4 b}$ \\
\hline $\mathrm{CV}^{\mathrm{b}}$ & 100 & 100 & 12.5 & 50 \\
$\mathrm{CS}^{\mathrm{c}}$ & 100 & 50 & 12.5 & 50 \\
$\mathrm{SS}^{\mathrm{d}}$ & 100 & 50 & 25 & 50
\end{tabular}

${ }^{\mathrm{a}}$ Actinomycin $\mathrm{C}_{2},{ }^{\mathrm{b}}$ Chlorella vulgaris, ${ }^{\mathrm{c}}$ Chlorella sorokiniana, ${ }^{\mathrm{d}}$ Scenedesmus subspicatus

organisms and pre-incubated at $24 \sim 26^{\circ} \mathrm{C}$ for one day in daylight. Test substances were added and results were recorded after 3 days (see Table 2). In addition, a known antibiotic, actinomycin D (AD) showed strong antimicroalgal activity and hence this was tested as a reference.

Compounds $\mathbf{1 b} \sim \mathbf{1 f}, \mathbf{3}, \mathbf{4 a} \sim \mathbf{4 b}$ did not show activity against Staphylococcus aureus, Bacillus subtilis, Escherichia coli, Streptomyces viridochromogenes, Candida albicans and Mucor miehei at concentrations up to $200 \mu \mathrm{g} / \mathrm{ml}$. The activity of the phenylethylamides is weaker than that of the previously described anthranilamides ${ }^{2}$.

\section{Experimental}

Material \& methods and biological tests were used as described earlier ${ }^{2}$.

\section{Isolation of the Strains GW73a, GW90a, and GW102b}

A sample of $c a$. $50 \mathrm{ml}$ was collected manually from a seepage channel and contained $15 \mathrm{mg} \mathrm{PCB} \mathrm{kg}{ }^{-1}$ (dry weight). Slurry microcosms were set up as described ${ }^{5)}$ by mixing $2 \mathrm{~g}$ of the sample with $18 \mathrm{ml}$ of $\mathrm{M} 9$ minimal medium and adding biphenyl crystals to yield a final concentration of $c a .650 \mu \mathrm{g} \mathrm{liter}^{-1}$ in the liquid phase. Slurries were shaken gently for 6 months on a rotatory shaker. Evaporated water and consumed biphenyl crystals were periodically replaced. An aliquot of $100 \mu \mathrm{l}$ was serially diluted in $0.85 \%$ (wt/vol) $\mathrm{NaCl}$, and appropriate dilutions were spread on agar plates containing $0.1 \times$ LuriaBertani (LB) medium ${ }^{6}$. Colonies which showed activity for the 2,3-dihydroxybiphenyl dioxygenase enzyme (spray test described in Lit. $^{5}$ ) were picked and subcultivated on 0.1 strength LB plates.

The strains are deposited in the culture collection of the Department of Microbiology at the National Research Institute for Biotechnology in Braunschweig, Germany.

\section{Algae Test Plates}

Strains of Chlorella vulgaris (SAG 211-11b), Chlorella sorokiniana (SAG 211-8k) and Scenedesmus subspicatus (SAG 86-81) were obtained from the Collection of Algae Cultures, Göttingen, Germany (SAG) and cultured in Bold's basal medium (BBM, 1) ${ }^{7)}$ modified by adding sterile-filtered $\mathrm{NaHCO}_{3}$ ( $50 \mathrm{~mm}$ final concentration). The algae were grown at $20^{\circ} \mathrm{C}$ and illuminated by white fluorescent tubes $\left[80 \mu \mathrm{mol}\right.$ photons $\mathrm{m}^{-2} \mathrm{~s}^{-1}, 14 / 10$ hours light-dark cycle] or daylight. Algae were harvested for testing after $10 \sim 14$ days at a cell density between $10^{7} \sim 10^{8}$ cells $/ \mathrm{ml}$.

The harvested algae were washed and resuspended in Bold's basal medium and were set at a cell density of $5 \times 10^{7}$ cells $/ \mathrm{ml}$. $2.5 \mathrm{ml}$ of the algae were added to $2.5 \mathrm{ml}$ of $1.5 \%$ agar in BBM [MBBM, 2] $\left(55 \sim 60^{\circ} \mathrm{C}\right)$ and immediately poured on Petri dishes containing $15 \mathrm{ml} \mathrm{BBM}$ [MBBM] plus $1.5 \%$ agar. The plates were incubated at room temperature for 24 hours and then used for the biological assay.

Fermentation of the Strains GW90a, GW102a and GW73a

The strains GW90a, GW102a and GW73a were separately inoculated from slant agar culture into $10 \times 1$ liter Erlenmeyer flasks each with $200 \mathrm{ml}$ of Luria-Bertani ${ }^{6)}$ medium and grown for 3 days at $29^{\circ} \mathrm{C}$ with $95 \mathrm{rpm}$. The shaken cultures of each strain served separately for the inoculation of 20-liter jar fermentors each containing 18 liters of the medium as above. Incubation was carried out for 3 days at $29^{\circ} \mathrm{C}$ and $120 \mathrm{rpm}$ with automatic addition of $2 \mathrm{~N} \mathrm{NaOH}$ and $2 \mathrm{~N} \mathrm{HCl}$ to maintain the $\mathrm{pH}$ at $6.5 \pm 1.25$. Niax was used as antifoaming agent and sterile air (5 liters/minute) was supplied. The culture broth of each fermentor was mixed with diatom earth (ca. $1 \mathrm{~kg}$ ) and passed through a pressure filter. The culture filtrate and biomass were extracted separately three times with $c a .10$ liters of ethyl acetate and the combined organic layers were evaporated to dryness to yield $4.12 \mathrm{~g}$ (GW90a), $2.40 \mathrm{~g}$ (GW102a) and $2.79 \mathrm{~g}$ (GW73a), respectively, of crude extracts.

The crude extracts were dissolved in methanol ( $c a$. $100 \mathrm{ml}$ ) and defatted with cyclohexane (ca. $100 \mathrm{ml})$. The methanol layers were concentrated, the residues were dried in vacuo and subjected to silica gel column 
chromatography $(65 \times 3 \mathrm{~cm})$ using $\mathrm{CHCl}_{3} / \mathrm{CH}_{3} \mathrm{OH}$ (GW90a and GW102a) and ethyl acetate/cyclohexane gradient to separate into 10 (GW90a) or 8 (GW102a and GW73a) fractions. Purification of the phytotoxic fraction 4 (GW90a) using HPLC, afforded three colourless compounds $N-\left(2^{\prime}\right.$-phenylethyl)propionamide (1b) (19 mg), $N-\left(2^{\prime}-\right.$ phenylethyl)isobutyramide (1c) (25 mg), 3-methyl- $N$-(2'phenylethyl)butyramide (1d) $(24 \mathrm{mg})$. Fraction 5 was purified on Sephadex $\mathrm{LH} 20\left(\mathrm{CHCl}_{3} / \mathrm{CH}_{3} \mathrm{OH} 6: 4\right)$ and delivered $N$-(2'-phenylethyl)propionamide (1b) (15 mg) and $N$-( 2 '-phenylethyl)hexanamide (1e) $(35 \mathrm{mg})$. Further purification of the fractions from GW102a afforded 1a $\sim 1 e$, 1f $(6 \mathrm{mg})$ and $2(2 \mathrm{mg})$. Separation of GW73a gave 1d (14 mg) and the known compounds $N$-(2-phenylethyl)acetamide (1a, $34 \mathrm{mg}), \quad N_{\beta}$-acetyltryptamine $(30 \mathrm{mg})$, cyclo(tyrosylprolyl) (66 mg), cyclo(leucylproplyl) (23 mg), uridine ( $9 \mathrm{mg})$, uracil (3 $\mathrm{mg})$, and anthranilic acid ( $7 \mathrm{mg}$ ).

\section{$N$-(2'-Phenylethyl)propionamide (1) $)$}

${ }^{1} \mathrm{H} \mathrm{NMR}\left(\mathrm{CDCl}_{3}, 300 \mathrm{MHz}\right) \delta 7.28(5 \mathrm{H}, \mathrm{m}, \mathrm{Ar}-\mathrm{H}), 5.50$ $\left(1 \mathrm{H}\right.$, brs, exchangeable with $\left.\mathrm{D}_{2} \mathrm{O}, \mathrm{N}-\mathrm{H}\right), 3.52(2 \mathrm{H}, \mathrm{q}$, $\left.J=8 \mathrm{~Hz}, 1^{\prime}-\mathrm{H}_{2}\right), 2.82\left(2 \mathrm{H}, \mathrm{t}, J=8 \mathrm{~Hz}, 2^{\prime}-\mathrm{H}_{2}\right), 2.18(2 \mathrm{H}, \mathrm{q}$, $\left.J=8 \mathrm{~Hz}, 2-\mathrm{H}_{2}\right), 1.10\left(3 \mathrm{H}, \mathrm{t}, J=8 \mathrm{~Hz}, 3-\mathrm{H}_{3}\right) .{ }^{1} \mathrm{H}$ NMR (acetone- $\left.d_{6}, 200 \mathrm{MHz}\right) \delta 7.24(5 \mathrm{H}, \mathrm{m}, \mathrm{Ar}-\mathrm{H}), 7.10(1 \mathrm{H}$, brs, exchangeable with $\left.\mathrm{D}_{2} \mathrm{O}, \mathrm{N}-\mathrm{H}\right), 3.40 \quad(2 \mathrm{H}, \quad \mathrm{q}$, $\left.{ }^{3} J=8.0 \mathrm{~Hz}, 1^{\prime}-\mathrm{H}_{2}\right), 2.77\left(2 \mathrm{H}, \mathrm{t}, J=8 \mathrm{~Hz}, 2^{\prime}-\mathrm{H}_{2}\right), 2.13(2 \mathrm{H}$, q, $\left.J=7.0 \mathrm{~Hz}, 2-\mathrm{H}_{2}\right), 1.04\left(3 \mathrm{H}, \mathrm{t}, J=7.0 \mathrm{~Hz}, 3-\mathrm{H}_{3}\right) \cdot{ }^{13} \mathrm{C} \mathrm{NMR}$ (acetone- $\left.d_{6}, 50.3 \mathrm{MHz}\right) \delta 174.0\left(\mathrm{C}_{\mathrm{q}}-1\right), 140.5\left(\mathrm{C}_{\mathrm{q}}-1^{\prime \prime}\right)$, 129.5 (CH-3", 5"-CH), 129.1 (CH-2", CH-6"), 126.9 (CH$\left.4^{\prime \prime}\right), 41.4\left(\mathrm{CH}_{2}-2\right), 41.3\left(\mathrm{CH}_{2}-1^{\prime}\right), 36.5\left(\mathrm{CH}_{2}-2^{\prime}\right), 10.2\left(\mathrm{CH}_{3}-\right.$ 3). EI-MS (70 eV) $m / z(\%) 177(\mathrm{M}, 68), 104\left(\mathrm{Ph}-\mathrm{CH}_{2} \mathrm{CH}_{2}\right.$, 100). CI-MS $\left(\mathrm{NH}_{3}\right) \mathrm{m} / z(\%) 372\left(\left[2 \mathrm{M}+\mathrm{NH}_{4}\right]^{+}, 38\right), 355$ $\left([2 \mathrm{M}+\mathrm{H}]^{+}, 100\right), 195\left(\left[\mathrm{M}+\mathrm{NH}_{4}\right]^{+}, 70\right), 178\left([\mathrm{M}+\mathrm{H}]^{+}\right.$, 38). IR (KBr) $v_{\max }\left(\mathrm{cm}^{-1}\right) 3276,3080,3028,2970,2934$, $1648,1558,1496,1454,1430,1375,1248,1198,1132$, $1049,885,749,701,573,497,466$.

\section{$N$-(2'-Phenylethyl)isobutyramide (1c)}

${ }^{1} \mathrm{H} \mathrm{NMR}\left(\mathrm{CDCl}_{3}, 300 \mathrm{MHz}\right) \delta 7.25(5 \mathrm{H}, \mathrm{m}, \mathrm{Ar}-\mathrm{H}), 5.50$ $\left(1 \mathrm{H}\right.$, brs, exchangeable with $\left.\mathrm{D}_{2} \mathrm{O}, \mathrm{N}-\mathrm{H}\right), 3.50(2 \mathrm{H}, \mathrm{q}$, $\left.J=8 \mathrm{~Hz}, 1^{\prime}-\mathrm{H}_{2}\right), 2.82\left(2 \mathrm{H}, \mathrm{t}, J=8 \mathrm{~Hz}, 2^{\prime}-\mathrm{H}_{2}\right), 2.30(1 \mathrm{H}, \mathrm{h}$, $J=8 \mathrm{~Hz}, 2-\mathrm{H}), 1.15\left(6 \mathrm{H}, \mathrm{d}, J=8 \mathrm{~Hz}, 3-\mathrm{H}_{3}, 4-\mathrm{H}_{3}\right) .{ }^{1} \mathrm{H}$ NMR (acetone- $\left.d_{6}, 200 \mathrm{MHz}\right) \delta 7.24(5 \mathrm{H}, \mathrm{m}, \mathrm{Ph}-\mathrm{H}), 7.04(1 \mathrm{H}$, brs, exchangeable with $\left.\mathrm{D}_{2} \mathrm{O}, \mathrm{N}-\mathrm{H}\right), 3.40(2 \mathrm{H}, \mathrm{q}$, $\left.{ }^{3} J=8.0 \mathrm{~Hz}, 1^{\prime}-\mathrm{H}_{2}\right), 2.77\left(2 \mathrm{H}, \mathrm{t}, J=8.0 \mathrm{~Hz}, 2^{\prime}-\mathrm{H}_{2}\right), 2.36(1 \mathrm{H}$, h, $J=8.0 \mathrm{~Hz}, 2-\mathrm{H}), 1.04\left(6 \mathrm{H}, \mathrm{d}, J=8.0 \mathrm{~Hz}, 3-\mathrm{H}_{3}, 4-\mathrm{H}_{3}\right) \cdot{ }^{13} \mathrm{C}$ $\operatorname{NMR}\left(\mathrm{CDCl}_{3}, 75.5 \mathrm{MHz}\right) \delta 174.0\left(\mathrm{C}_{\mathrm{q}}-1\right), 140.5\left(\mathrm{C}_{\mathrm{q}}-1^{\prime \prime}\right)$, 128.8 (CH-3", CH-5"), 128.6 (CH-2", CH-6"), 126.5 (CH$\left.4^{\prime \prime}\right), 40.5\left(\mathrm{CH}_{2}-1^{\prime}\right), 35.7\left(\mathrm{CH}_{2}-2^{\prime}\right), 35.6(\mathrm{CH}-2), 19.6\left(\mathrm{CH}_{3}-\right.$ 2, $\left.\mathrm{CH}_{3}-4\right) .{ }^{13} \mathrm{C}$ NMR (acetone- $\left.d_{6}, 50.3 \mathrm{MHz}\right) \delta 176.7\left(\mathrm{C}_{\mathrm{q}}-\right.$
1), $140.5\left(\mathrm{C}_{\mathrm{q}}-1^{\prime \prime}\right), 129.6\left(\mathrm{CH}-3^{\prime \prime}, \mathrm{CH}-5^{\prime \prime}\right), 129.1$ (CH-2", $\left.\mathrm{CH}-6^{\prime \prime}\right), 126.9\left(\mathrm{CH}-4^{\prime \prime}\right), 41.3\left(\mathrm{CH}_{2}-1^{\prime}\right), 36.5\left(\mathrm{CH}_{2}-2^{\prime}\right), 35.6$ $(\mathrm{CH}-2), 19.9\left(\mathrm{CH}_{3}-3, \mathrm{CH}_{3}-4\right)$. EI-MS $(70 \mathrm{eV}) \mathrm{m} / \mathrm{z}(\%)$ 191.1 (M, 44), $104.0\left(\mathrm{Ph}-\mathrm{CH}_{2} \mathrm{CH}_{2}, 100\right), 71.0$ (40). IR (KBr) $v_{\max }\left(\mathrm{cm}^{-1}\right) 3300,3086,2967,2871,1641,1548$, $1458,1363,1242,1195,1101,748,698,486$.

\section{$N$-(2'-Phenylethyl)isovaleramide (1d)}

${ }^{1} \mathrm{H} \mathrm{NMR}\left(\mathrm{CDCl}_{3}, 300 \mathrm{MHz}\right) \delta 7.28(5 \mathrm{H}, \mathrm{m}, \mathrm{Ar}-\mathrm{H}), 5.56$ $\left(1 \mathrm{H}\right.$, brs, exchangeable with $\left.\mathrm{D}_{2} \mathrm{O}, \mathrm{N}-\mathrm{H}\right), 3.56(2 \mathrm{H}, \mathrm{q}$, $\left.J=8 \mathrm{~Hz}, 1^{\prime}-\mathrm{H}_{2}\right), 2.82\left(2 \mathrm{H}, \mathrm{t}, J=8 \mathrm{~Hz}, 2^{\prime}-\mathrm{H}_{2}\right), 2.06(1 \mathrm{H}, \mathrm{s}$, $J=8 \mathrm{~Hz}, 3-\mathrm{H}), 1.98\left(2 \mathrm{H}, \mathrm{d}, J=8 \mathrm{~Hz}, 2-\mathrm{H}_{2}\right), 0.92(6 \mathrm{H}, \mathrm{d}$, $\left.J=8 \mathrm{~Hz}, 4-\mathrm{H}_{3}, 5-\mathrm{H}_{3}\right) \cdot{ }^{13} \mathrm{C} \mathrm{NMR}\left(\mathrm{CDCl}_{3}, 75.5 \mathrm{MHz}\right) \delta 172.9$ $\left(\mathrm{C}_{\mathrm{q}}-1\right), 138.9\left(\mathrm{C}_{\mathrm{q}}-1^{\prime \prime}\right), 128.7$ (CH-3", $\left.\mathrm{CH}-5^{\prime \prime}\right), 128.6$ (CH-2", CH-6"), 126.5 (CH-4"), $46.1\left(\mathrm{CH}_{2}-2\right), 40.6\left(\mathrm{CH}_{2}-1^{\prime}\right), 35.7$ $\left(\mathrm{CH}_{2}-2^{\prime}\right), 26.2(\mathrm{CH}-3), 22.4\left(\mathrm{CH}_{3}-4, \mathrm{CH}_{3}-5\right)$. CI-MS $\left(\mathrm{NH}_{3}\right)$ $m / z(\%) 206.1\left([\mathrm{M}+\mathrm{H}]^{+}, 28\right), 223.1\left([\mathrm{M}+\mathrm{H}]^{+}, 100\right), 240.1$ $\left(\left[\mathrm{M}+\mathrm{NH}_{3}+\mathrm{NH}_{4}\right]^{+}, 15\right), 411.1\left([2 \mathrm{M}+\mathrm{H}]^{+}, 28\right), 428.1$ $\left(\left[2 \mathrm{M}+\mathrm{NH}_{4}+\mathrm{NH}_{3}\right]^{+}, 42\right)$. IR $(\mathrm{KBr}) v_{\max }\left(\mathrm{cm}^{-1}\right) 3302$, 2959, 2868, 1639, 1545, 1456, 1368, 1308, 1198, 1131, $1031,748,699,605,496$.

\section{$N$-(2'-Phenylethyl)hexanamide (1e)}

${ }^{1} \mathrm{H} \mathrm{NMR}\left(\mathrm{CDCl}_{3}, 300 \mathrm{MHz}\right) \delta 7.24(5 \mathrm{H}, \mathrm{m}, \mathrm{Ar}-\mathrm{H}), 5.48$ $\left(1 \mathrm{H}\right.$, br s, exchangeable with $\left.\mathrm{D}_{2} \mathrm{O}, \mathrm{N}-\mathrm{H}\right), 3.50(2 \mathrm{H}, \mathrm{q}$, $\left.J=8 \mathrm{~Hz}, 1^{\prime}-\mathrm{H}_{2}\right), 2.80\left(2 \mathrm{H}, \mathrm{t}, J=8 \mathrm{~Hz}, 2^{\prime}-\mathrm{H}_{2}\right), 2.10(2 \mathrm{H}, \mathrm{t}$, $\left.J=8 \mathrm{~Hz}, 2-\mathrm{H}_{2}\right), 1.60\left(2 \mathrm{H}, \mathrm{q}, J=8 \mathrm{~Hz}, 3-\mathrm{H}_{2}\right), 1.28(4 \mathrm{H}, \mathrm{m}, 4-$ $\left.\mathrm{H}_{2}, 5-\mathrm{H}_{2}\right), 0.85\left(3 \mathrm{H}, \mathrm{t}, J=8 \mathrm{~Hz}, 6-\mathrm{H}_{3}\right) .{ }^{13} \mathrm{C} \mathrm{NMR}\left(\mathrm{CDCl}_{3}\right.$, $75.5 \mathrm{MHz}) \delta 173.3\left(\mathrm{C}_{\mathrm{q}}-1\right), 138.5\left(\mathrm{C}_{\mathrm{q}}{ }^{-1}{ }^{\prime \prime}\right), 128.7\left(\mathrm{CH}-3^{\prime \prime}\right.$, CH-5"), 128.6 (CH-2", CH-6"), $126.5\left(\mathrm{CH}-4^{\prime \prime}\right), 40.6\left(\mathrm{CH}_{2}-\right.$ $\left.1^{\prime}\right), 36.7\left(\mathrm{CH}_{2}-2\right), 35.7\left(\mathrm{CH}_{2}-2^{\prime}\right), 31.4\left(\mathrm{CH}_{2}-3\right), 26.5\left(\mathrm{CH}_{2}-\right.$ 4), $22.4\left(\mathrm{CH}_{2}-5\right), 13.9\left(\mathrm{CH}_{3}-6\right)$. CI-MS $\left(\mathrm{NH}_{3}\right) \mathrm{m} / \mathrm{z}(\%) 220$ $\left([\mathrm{M}+\mathrm{H}]^{+}, 32\right), 237\left(\left[\mathrm{M}+\mathrm{NH}_{4}\right]^{+}, 100\right), 439\left([2 \mathrm{M}+\mathrm{H}]^{+}\right.$, $20), 456\left(\left[2 \mathrm{M}+\mathrm{NH}_{4}\right]^{+}, 18\right) . \mathrm{IR}(\mathrm{KBr}) v_{\max }\left(\mathrm{cm}^{-1}\right) 3303$, 2929, 2864, 1640, 1548, 1455, 1373, 1252, 1195, 1116, $747,699,497$.

\section{2-Methyl- $N$-(2' -phenylethyl)butyramide (1f)}

${ }^{1} \mathrm{H} \mathrm{NMR}\left(\mathrm{CDCl}_{3}, 200 \mathrm{MHz}\right) \delta 7.26(5 \mathrm{H}, \mathrm{m}, \mathrm{Ph}-\mathrm{H}), 5.48$ $\left(1 \mathrm{H}\right.$, br s, N-H), $3.54\left(2 \mathrm{H}, \mathrm{q},{ }^{3} J=8.0 \mathrm{~Hz}, 1^{\prime}-\mathrm{H}_{2}\right), 2.82(2 \mathrm{H}$, $\left.\mathrm{t},{ }^{3} \mathrm{~J}=8.0 \mathrm{~Hz}, 2^{\prime}-\mathrm{H}_{2}\right), 2.01\left(1 \mathrm{H}\right.$, sext, $\left.{ }^{3} \mathrm{~J}=8.0 \mathrm{~Hz}, 2-\mathrm{H}\right), 1.63$ $\left(1 \mathrm{H}, \mathrm{h},{ }^{3} J=8.0 \mathrm{~Hz}, 3-\mathrm{H}\right), 1.39\left(1 \mathrm{H}, \mathrm{h},{ }^{3} J=8.0 \mathrm{~Hz}, 3-\mathrm{H}\right), 1.07$ $\left(3 \mathrm{H}, \mathrm{d},{ }^{3} J=8.0 \mathrm{~Hz}, 5-\mathrm{Me}\right), 0.86\left(3 \mathrm{H}, \mathrm{t},{ }^{3} J=8.0 \mathrm{~Hz}, 4-\mathrm{Me}\right)$. ${ }^{13} \mathrm{C}$ NMR (acetone- $\left.d_{6}, 50.3 \mathrm{MHz}\right) \delta 176.3\left(\mathrm{C}_{\mathrm{q}}-1\right), 140.6$ $\left(\mathrm{C}_{\mathrm{q}}-1^{\prime \prime}\right), 129.5$ (CH-3", CH-5"), 129.1 (CH-2", $\left.\mathrm{CH}-6^{\prime \prime}\right)$, $126.8\left(\mathrm{CH}-4^{\prime \prime}\right), 43.1\left(\mathrm{CH}_{2}-1^{\prime}\right), 41.2(\mathrm{CH}-2), 36.6\left(\mathrm{CH}_{2}-2^{\prime}\right)$, $27.9\left(\mathrm{CH}_{2}-3\right), 18.1\left(\mathrm{CH}_{3}-5\right), 12.2\left(\mathrm{CH}_{3}-4\right)$. EI-MS $(70 \mathrm{eV})$ $m / z(\%) 205$ (M, 80), $104\left(\mathrm{Ph}_{-} \mathrm{CH}_{2} \mathrm{CH}_{2}, 100\right), 85$ (60), 57 (66). IR (KBr) $v_{\max }\left(\mathrm{cm}^{-1}\right) 3316,3086,2963,2928,2873$, $1742,1641,1557,1453,1380,1233,1029,750,701,570$, 
492.

cyclo(Isoleucyldehydroalanyl) (2)

White solid, m.p. $215 \sim 220^{\circ} \mathrm{C}$ (with decomposition), $\mathrm{Rf}=0.20 \quad\left(\mathrm{CHCl}_{3} / 5 \% \quad \mathrm{MeOH}\right) . \quad{ }^{1} \mathrm{H} \quad \mathrm{NMR} \quad\left(\right.$ DMSO- $d_{6}$, $300 \mathrm{MHz}) \delta 10.44\left(1 \mathrm{H}\right.$, br s, exchangeable with $\mathrm{D}_{2} \mathrm{O}, 1-$ $\mathrm{NH}), 8.38\left(1 \mathrm{H}\right.$, brs, exchangeable with $\left.\mathrm{D}_{2} \mathrm{O}, 4-\mathrm{NH}\right), 5.18$ $\left(1 \mathrm{H}, \mathrm{s}, 11-\mathrm{H}_{\mathrm{A}}\right), 4.78\left(1 \mathrm{H}, \mathrm{s}, 11-\mathrm{H}_{\mathrm{B}}\right), 3.96(1 \mathrm{H}, \mathrm{dt}$, $\left.{ }^{3} J=4.0 \mathrm{~Hz},{ }^{3} J=8.0 \mathrm{~Hz}, 6-\mathrm{H}\right), 1.80(1 \mathrm{H}, \mathrm{m}, 8-\mathrm{H}), 1.56(2 \mathrm{H}$, $\left.\mathrm{dt},{ }^{4} J=2.0 \mathrm{~Hz},{ }^{3} J=8.0 \mathrm{~Hz}, 7-\mathrm{H}_{2}\right), 0.86\left(6 \mathrm{H}, \mathrm{d},{ }^{3} J=8.0 \mathrm{~Hz}\right.$, 9,10- $\left.\mathrm{CH}_{3}\right) \cdot{ }^{13} \mathrm{C}$ NMR (DMSO- $\left.d_{6}, 50.3 \mathrm{MHz}\right) \delta 166.4\left(\mathrm{C}_{\mathrm{q}}\right.$ 5), $158.2\left(\mathrm{C}_{\mathrm{q}}-2\right), 134.6\left(\mathrm{C}_{\mathrm{q}}-3\right), 98.9\left(\mathrm{CH}_{2}-11\right), 53.7(\mathrm{CH}-6)$, $43.5\left(\mathrm{CH}_{2}-7\right), 22.6(\mathrm{CH}-8), 22.1\left(\mathrm{CH}_{3}-9, \mathrm{CH}_{3}-10\right)$. HMQC (DMSO- $d_{6}$, INVBTP, F1 $125.7 \mathrm{MHz}$, F2 $\left.500 \mathrm{MHz}\right)(\mathrm{H} \rightarrow \mathrm{C})$ $11-\mathrm{H} \rightarrow \mathrm{C}-11 ; 11-\mathrm{H} \rightarrow \mathrm{C}-11 ; 6-\mathrm{H} \rightarrow \mathrm{C}-6 ; 8-\mathrm{H} \rightarrow \mathrm{C}-8 ; 7-\mathrm{H} \rightarrow$ $\mathrm{C}-7 ; \quad 9-\mathrm{H} \rightarrow \mathrm{C}-9 ; \quad 10-\mathrm{H} \rightarrow \mathrm{C}-10 . \quad \mathrm{HMBC} \quad$ (DMSO- $d_{6}$, IN4LPLRND, F1 $125.7 \mathrm{MHz}, \mathrm{F} 2500 \mathrm{MHz})(\mathrm{H} \rightarrow \mathrm{C}) 1-\mathrm{H}$ ${ }^{2} J \rightarrow \mathrm{C}-2 ; 1-\mathrm{H}^{3} J \rightarrow \mathrm{C}-7 ; 4-\mathrm{H}^{2} J \rightarrow \mathrm{C}-3, \mathrm{C}-5 ; 11-\mathrm{H}_{2}{ }^{2} J \rightarrow \mathrm{C}-3$; $11-\mathrm{H}_{2}{ }^{3} \mathrm{~J} \rightarrow \mathrm{C}-2 ; 11-\mathrm{H}_{2}{ }^{4} \mathrm{~J} \rightarrow \mathrm{C}-5 ; 6-\mathrm{H}^{2} J \rightarrow \mathrm{C}-5$, C-7; 6-H ${ }^{3} J \rightarrow \mathrm{C}-2, \mathrm{C}-8 ; 8-\mathrm{H}^{2} J \rightarrow \mathrm{C}-7, \mathrm{C}-9, \mathrm{C}-10 ; 8-\mathrm{H}^{3} J \rightarrow \mathrm{C}-6 ; 7-\mathrm{H}_{2}$ ${ }^{3} J \rightarrow \mathrm{C}-5 ; 9-\mathrm{H}^{2} J \rightarrow \mathrm{C}-8 ; 9-\mathrm{H}^{3} J \rightarrow \mathrm{C}-7 ; 10-\mathrm{H}^{2} J \rightarrow \mathrm{C}-8 ; 10-\mathrm{H}$ ${ }^{3} \mathrm{~J} \rightarrow \mathrm{C}-7$. DCI-MS $\left(\mathrm{NH}_{3}\right) \mathrm{m} / \mathrm{z}(\%) 365\left([2 \mathrm{M}+1]^{+}, 2\right), 217$ $\left([\mathrm{M}+18+17]^{+}, 24\right), 200\left([\mathrm{M}+18]^{+}, 100\right), 183\left([\mathrm{M}+1]^{+}\right.$, 12).

$$
\begin{array}{lll}
\text { EI-HRMS } & \text { Calcd for } \mathrm{C}_{9} \mathrm{H}_{14} \mathrm{~N}_{2} \mathrm{O}_{2}: & 182.10552 \\
& \text { Found: } & 182.1055
\end{array}
$$

\section{Acknowledgments}

We thank Dr. G. Remberg and Mr. R. Machinek for the spectral measurements. This work was supported by a grant from the Bundesministerium für Bildung und Forschung
(BMBF, grant 0310735). R.P.M is thankful to the DAAD for financial assistance, R.N.A. thanks the State of Lower Saxony (Germany) for a grant in the research program for young talented Non-European scientists.

\section{References}

1) Wagner-Döbler, I.; W. Beil, S. Lang, M. Meiners \& H. LAATSCH: Integrated Approach to Explore the Potential of Marine Microorganisms for the Production of Bioactive Metabolites, in Advances in Biochemical Engineering/Biotechnology, special ed. "Tools and Applications of Biochemical Engineering", 74: 207 238, 2002

2) Biabani, M. A. F.; M. BaAKe, B. Lovisetto, H. LAATSCH, E. HelmKe \& H. Weyland: Anthranilamides: New antimicroalgal active substances from a marine Streptomyces sp. J. Antibiotics 51: 333 340, 1998

3) LAATSCH, H.: AntiBase 2000, A Natural Products Database for Rapid Structure Determination. Chemical Concepts, Weinheim 2000; see Internet http://www.gwdg.de/ ucoc/Laatsch/

4) Kwon, O. S.; S. H. Park, B.-S. Yun, Y. R. Pyun \& C.-J. KIM: Cyclo(dehydroala-L-Leu), an a-glucosidase inhibitor from Penicillium sp. J. Antibiotics 53: 954 958, 2000

5) Wagner-Döbler, I.; A. Bennasar, M. Vancanneyt, S. STRÖMPL, I. BRÜMMER, C. EICHNER, I. GRAMMEL \& E.R.B. MoORE: Microcosm enrichment of biphenyldegrading microbial communities from soils and sediments. Appl. Environ. Microb. 64: 3014 3022, 1998

6) Luria-Bertani-medium: Tryptone $(10 \mathrm{~g})$, yeast extract $(5 \mathrm{~g})$ and $\mathrm{NaCl}(10 \mathrm{~g})$ were dissolved in 1 liter of tap water and the medium was adjusted to $\mathrm{pH} 7.2$ with $2 \mathrm{~N}$ $\mathrm{NaOH}$ and sterilised for 33 minutes at $121^{\circ} \mathrm{C}$

7) Nicols, H. W. \& M. C. Bold: Trichsacina polymorpha Gen. et sp. nov. J. Phycol. 1: 34 38, 1965 